\title{
Flyktningnasjonalisme: Fra Nakba til PLO
}

Den palestinske nasjonale identiteten ble skapt i Palestina, men det var flukten fra Palestina som dannet den samlende erfaringen som ble basisen for den altomfattende palestinske nasjonalismen. Eksilet skapte ikke nasjonalismen, men styrket den ved å definere og demokratisere den. 
TEKST: Jørgen Jensehaugen

BEGREPET NASJONALISME er både mye brukt og meget omdiskutert. Det er en politisk tanke som ble utviklet sent på I8oo-tallet i Europa. Det å definere noe som en nasjon, eller å hevde at en form for nasjonalisme for et gitt folk eksisterer er ofte vanskeligere enn det høres ut. Som vi skal se er det ikke mindre vanskelig $\mathrm{i}$ en så politisert kontekst som den palestinske. Vi skal her diskutere hvordan den palestinske nasjonalismen utviklet seg i en historisk kontekst i lys av teoretiske tilnærminger til nasjonalismebegrepet.

I litteraturen generelt finner man to dominerende syn på palestinsk nasjonalisme som fenomen. Begge disse forståelsene har generelt vært basert mer på ideologisk drevet tenkning enn av forskning. Fra sionistisk/israelsk hold har det blitt vanlig å hevde at en palestinsk nasjon aldri har eksistert, og at det er en ren konstruksjon som ble skapt som en reaksjon på Israels tilblivelse. Fra palestinsk hold har det motsatte blitt argumentert, nemlig at den palestinske nasjonen er noe som alltid

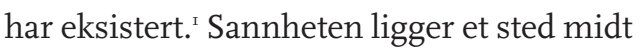
i mellom. Den palestinske nasjonen, som alle andre nasjoner, og den palestinske nasjonalismen som et ideologisk uttrykk for denne, er et moderne fenomen og således en konstruksjon, eller det Benedict Anderson kaller en «Imagined Community». ${ }^{2}$ Utrykket beskriver hvordan en befolkningsgruppe gradvis «forestiller» seg selv som en nasjon ved tettere intern kommunikasjon, gjennom for eksempel aviser, trykkpresser, og så videre. Dette kan beskrives som en overgang fra det å være mindre samfunn (landsbyer, storfamilier og lignende) til å se på seg selv som et helhetlig samfunn, en nasjon. Denne utviklingen er like gyldig for sionismen, og den resulterende staten, Israel, som for den palestinske nasjonalismen, da begge ble konstruert i moderne tid. ${ }^{3}$ Palestinsk nasjonalisme er hverken mer eller mindre kunstig enn andre nasjonalismer. Ingen nasjonalisme oppstår plutselig, ut av intet, ei heller den palestinske.

Palestinsk nasjonal identitet ble skapt under det britiske mandatet, vokste opp som et eliteprosjekt, fikk gradvis folkelig grobunn under det palestinske opprøret i I936, og fikk sin fullstendige nedenfra-ogopp karakter etter flukten fra Palestina i I948. ${ }^{4} \mathrm{Vi}$ skal her undersøke et tilsynelatende paradoks - hvordan kan det ha seg at den palestinske nasjonalisme ble først fullt utviklet etter at nasjonen, som geografisk sted, hadde blitt ødelagt? Dette er bare et tilsynelatende paradoks da det nettopp var flukten som skapte den absolutte samlende 
identitserfaringen som befestet nasjonalismen som folkelig ideologi.

\section{Hva er nasjonalisme?}

I følge samfunnsgeografen Jan Penrose er nasjonalisme «the product of three elements: a distinctive group of people, the territory which they occupy, and the bonding over time (of historical experience) which melds people and land into a "natural" whole.»v For å tilpasse dette til det palestinske tilfellet er det nødvendig å endre det andre elementet til «the territory which they occupied». Nasjonalisme kan dermed på mange måter anses som en kombinasjon av identitetsfornektelse og - bekreftelse knyttet til et spesifikt geografisk område. Lik enhver annen form for identitet, er nasjonalisme på den ene siden en bekreftelse av hvem man er (egenart/identitet), og på den andre siden en fornektelse av hvem man ikke er (den signifikante andre). I det norske tilfelle så denne kombinasjonen slik ut: Vi er nordmenn, vi er ikke svensker/dansker. Gjennom å befeste en slik identitet i geografi og institusjoner vokste nasjonalismen fram over hele verden, med idéhistorisk utgangspunkt i Europa. Forståelsen av denne selvforsterkende dynamikken har dannet grunnlaget for mye av den moderne nasjonalismeforskningen. ${ }^{6}$

Problemet i forhold til nasjonalisme innen den arabiske verden har vært at da det osmanske riket raknet og grensene ble tegnet på nytt av kolonimaktene Storbritannia og Frankrike, var det vanskelig å kombinere disse to - bekreftelse og fornektelse. For mange av disse landene ble statene etablert uten at det fantes en spesifik nasjonal identitet. Med mulige unntak av Egypt hadde ingen av de arabiske land- ene noen naturlige nasjonskarakteristika, og grensene var ofte kunstige. For størsteparten av befolkningen i disse områdene var identitetsligningen: Vi er arabere, vi er ikke tyrkere. Det var tross alt motstanden mot Tyrkia/det osmanske riket som var det første uttrykket for arabisk nasjonalisme. Like fullt var ikke det en statsbasert motstand, men heller en anti-tyrkisk/osmansk

Det tapte Palestina ble essensen $i$ en nåtidig tilvoerelse som blir ansett som et midlertidig oppholdssted for man skal vende hjem.

arabisk motstand.7 Araberne tilhørte samme etniske gruppe, snakket samme språk, hadde samme religion og mer eller mindre samme kultur. Dette banet veien for pan-arabisme, men gjorde det ikke nødvendigvis mulig for nasjonalisme i klassisk forstand å vokse fram. Historikeren Eric Hobsbawm kaller et slikt fenomen for «supra-nationalist», altså tilfeller hvor språklige og kulturelle identitetsstørrelser overskrider rammene for den moderne staten. ${ }^{8}$ For nesten samtlige av de gjeldende landene var innbyggerne muslimske arabere som hadde arabisk som felles språk. Kulturelt var grensene flytende. Resultatet av dette kan ses gjennom en gjennomgang av noen av de politiske ideologiene som har dominert araberverden i etterkrigstiden pan-arabismen, nasserismen, islamismen, og til en viss grad kommunismen. Samtlige av disse politiske ideologiene har en supra-nasjonal karakter. Ingen av dem har utgangspunkt i den enkelte nasjonen. 
Situasjonen i Palestina før I948-krigen var på mange måter lik den som eksisterte over hele araberverden. ${ }^{9}$ Det har lenge vært debattert om det i det hele tatt kan sies å ha eksistert en palestinsk nasjonalisme før I948, men det er ingen tvil om at den gradvis kom til å dominere etter I948.

For å kunne forstå dette tilsynelatende paradokset er det nødvendig å undersøke noen av de premissene nasjonalismeforskere har påpekt som nødvendige for dannelsen av nasjonalisme som ideologi, det vil si, hva som skal til for at en gruppe mennesker skal se på seg selv om en nasjon. For å forstå hvordan dette kom til å oppstå gradvis i det palestinske tilfellet er det nødvendig å gå tilbake $\mathrm{i}$ palestinsk historie til den palestinske nasjonalismens spede begynnelse.

\section{I936: Nasjonalistisk embryo}

Selv om nasjonalisme ikke var den førende ideologien i den arabiske verden i perioden før, under eller mellom verdenskrigene, vokste det i det palestinske tilfellet fram en form for proto-nasjonalisme, eller patriotisme. Likevel, hevder Yezid Sayigh, var dette aldri hovedidentiteten til palestinerne: «Palestinian-ism remained only one of the several strands of identity that Palestinians operated varyingly as the situation required. It was subsumed within a broader anti-colonial patriotism, along with clan, place of origin, religion, and Arab (or panSyrian) ethnicity.» ${ }^{\text {ㅇ }}$ Som ideologi vokste palestinsk nasjonalisme fram hovedsaklig rundt en urban intellektuell elite på ı9ıo-, 20- og 30-tallet. Den ble skapt rundt aviser som Filastin, al-Munadi og al-Quds, og i byer som Jerusalem, Nablus, Hebron, Jaffa og Gaza. ${ }^{\text {II I }}$ løpet av denne perioden ble det også etablert «nasjonale» merkedager. Fra
I9I 8 begynte man årlig å markere Balfourdagen, og fra I930 begynte man å markere

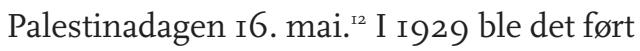
en debatt $\mathrm{i}$ avisen Filastin om opprettelsen av et palestinsk flagg og nasjonalsang. Denne debatten eksemplifiserer tydelig hvordan den tidlige palestinske nasjonalismen var et eliteprosjekt. For selv om det kom inn en rekke forslag om et partikularistisk palestinsk flagg, ble det til slutt det «arabiske» flagget som vant gjennom fordi det var supra-nasjonalismen, eller panarabismen de fleste identifiserte seg med. ${ }^{\mathrm{I}}$

Den elite-dominerte nasjonalismen ble delvis endret med opprøret i Palestina i I936, som hadde en entydig palestinsk karakter og som fant sted i alle samfunnsgrupper. På samme måte som den første intifadaen, litt over femti år senere, startet det palestinske opprøret i I936 med at en enkeltstående voldshendelse tente en gnist $i$ et samfunn hvor spenningene var ekstremt høye. Det var klare motsetninger både internt $\mathrm{i}$ det palestinske samfunnet, og mot de imperialistiske kreftene, slik man så dem - britene og sionistene. En viktig faktor i denne perioden var bevisstgjøringen blandt de palestinske bøndene som ble aktive deltagere i en landsomfattende protest. De sluttet å se på seg selv som bare landsbyboere, og de ble del av en nasjonal bevegelse. ${ }^{\mathrm{I}}$

Opprøret spredte seg raskt. Den startet delvis som en serie med spontane enkelthandlinger, men den ble raskt organisert av urbane foreninger og førte til dannelsen av den arabisk høy-komité (AHC) som ble palestinernes politiske lederskap. Geriljagrupper vokste opp på landsbygda og nye lederskikkelser dukket opp. Det anslås at opptil I5 000 palestinere var aktive geriljasoldater i opprøret. Britene slo etterhvert 
hardt ned på opptøyene, både i byene og på landsbygda. Opp mot 5000 palestinere mistet livet. ${ }^{15}$ Det palestinske lederskapet og de prominente politiske figurene ble enten drept eller drevet i eksil. Slik var I936 på mange måter en mindre utgave av den generelle tendensen - palestinsk nasjonalisme ble født hjemme, men vokste opp i eksil. Den palestinske nasjonalstreiken og -opprøret hadde en folkelig karakter og åpnet øynene til sionistene for at palestinerne var et folk med nasjonale ambisjoner. $^{16}$

Opprøret snudde på mange måter opp ned på det palestinske samfunnet. Det politiske lederskapet var blitt drept, eller utvist av landet. Det urbane borgerskapet

\section{mom \\ Som det palestinske folk $i$ sin helhet ble mange av de parastatlige institusjonene til PLO bevegelige enheter som manøvrerte i eksil.}

og de palestinske bøndene hadde organisert seg på en måte man ikke hadde sett før. Speiderbevegelser, fagforeninger og landsbyorganisasjoner vokste fram. En viktig identits- og instisjonsbygningsfaktor i denne perioden var det palestinske nasjonale skolevesenet som i følge en britisk rapport ble «seminaries of Arab nationalism $»{ }^{17}$

Resultatet av opprøret var at det ble skapt en sosial og nasjonal organisering, politisering og kollektiv erfaringsbase som ikke hadde eksistert på samme måte tidligere. Elite-nasjonalismen som hadde dominerte fram til da ble delvis erstattet av en folke- nasjonalisme..$^{8}$ «[T] he revolt was a distinct watershed, crystallizing the Palestinian national identity as nothing before. [...] the revolt helped to create a nation - even while crippling its social and political basis. ${ }^{19}$ Hvis denne påstanden var sann for I936-opprøret er den enda mer gyldig for I948-opprivningen.

\section{I948: Flukten}

Over hodet på palestinerne vedtok FN den 29. november I947 at Palestina skulle deles. Dagen etter brøt det ut borgerkrig i landet mellom sionistisk milits og palestinere. I5. mai I948 erklærte Israel sin uavhengighet og araberlandene svarte med invasjon. Som et kombinert resultat av sionistisk styrke, arabisk svakhet og et ødelagt palestinsk samfunn grunnet det mislykkede I936-opprøret, ble både borgerkrigen i I947-48 og krigen i I948-49 knusende nederlag for araberne generelt og palestinerne spesielt. I det området som ble Israel ble rundt 750 000 av 900 000 palestinere drevet på flukt. ${ }^{2 \circ}$ Dette var den palestinske katastrofen - al-Nakba.

Palestina som nasjonal enhet ble med dette rasert og palestinerne ble enten annenrangs borgere i Israel og Jordan, eller statsløse flyktninger i de omkringliggende araberlandene. Med unntak av i Jordan og Israel forble dermed palestinerne et folk uten land og nasjonalitet. Paradokset er at det var i dette fraværet at nasjonalismen vokste fram som den domirende ideologien i det palestinske samfunnet. Det var som et resultat av den kollektive flyktningerfaringen og raseringen av samfunnet at det ble et akutt behov for å skape en nasjon i moderne forstand. Og det var nettopp i flyktningleierene at denne transformasjonen fant sted. Den kollektive erfaring- 
en/erindringen ble formet og de parastatlige institusjonene ble dannet. Vi skal se på begge disse utviklingene.

\section{Flyktningidentitet}

Overgangen fra å tenke på Palestina som et rent geografisk sted man hadde bodd i, til å tenke på det som et nasjonalt hjem var et direkte resultat av den enorme felleserfaringen det var for palestinerne å bli kastet ut av hjemlandet sitt. ${ }^{2 \mathrm{I}}$ «[T] he common experience of Zionist settlement and conquest is what has created a Palestinian nationalism associated with a territory which, until I9I5 did not have any significant identity within southern Syria, to which it belonged,» hevder Hobsbawm. ${ }^{22}$ Hvis vi går tilbake til et tidligere poeng ser vi at denne fellesopplevelsen nettopp gjorde at både bekreftelses- og fornektelsesdelen av den nasjonalistiske ligningen fikk en fastlagt form. «Vi er palestinere, vi er ikke israelere.» I tillegg fikk flyktningerfaringen en ekstra dybde ved at de palestinske flyktningene ikke ble integrert i de arabiske landene. Påstanden «vi er arabere» fikk en tom klang. Man snakket samme språk, man hadde samme etniske opphav, men man var ikke «hjemme». Palestinerne fikk raskt føle at de ikke var syrere, ikke jordanere, ikke libanesere og så videre. I Jordan gikk man til og med så langt som å forby ordet «palestiner». ${ }^{23}$ Vi er palestinere ble dermed en akutt identitetssak med to signifikante andre. Selve det å hevde sin identitet ble synonymt med gjøre motstand. Det å ikke bli integrert i noen av sine mottakersamfunn gjorde også at ideen om den palestinske etnisiteten ble forsterket gjennom familiemønstre. Palestinere giftet seg med palestinere og fødte palestinere. ${ }^{24}$ Nasjon og etnisitet ble sammenknyttede størrelser.
I mange tilfeller bygde også strukturene i flyktningtilværelsen på samfunnsstrukturen slik den hadde eksisterte i Palestina før flukten. Flyktningleirene «kopierte» på et vis landsbyene man hadde flyktet fra ved at folk slo seg ned sammen med andre flyktninger fra opprinnelseslandsbyen. ${ }^{25}$

Opplevelsen av å bli redusert til flyktninger gjorde at Palestina, som geografisk enhet, fikk en symbolsk betydning som et «tapt paradis». ${ }^{26}$ Denne symbolske verdien av hjemlandet kommer tydelig til uttrykk i poesien til Mahmoud Darwish, den nylig avdøde palestinske nasjonalpoeten. Temaet går igjen i hans poesi med titler som «Unfortunately, It Was Paradise», og strofer som "I am the Adam of two Edens lost to me twice" og

Let it howl around your house,

bemoaning the perfect time, the golden age that is past.

I have no homeland, but...

In migration I love you more." ${ }^{27}$

Det samme referanseinnholdet finner man i palestinsk historiografi, hvor palestinske historikere i stor grad har forsket på det samfunnet som var, med titler som «All that remains», «Before their Diaspora» og «From Haven to Conquest». Man katalogiserte det tapte og viste til et samfunn som hadde vært, og definerte sin egenart med referanse til fortiden. ${ }^{28}$

Mange av de palestinske nasjonalsymbolene refererer på samme måte tilbake til dette tapte paradis, Palestina, og er dermed direkte resultater av flyktningerfaringen. Det tydeligste er symbolverdien til nøklene og eiendomspapirene til det huset familien forlot i I948. ${ }^{29}$ PLO institusjonaliserte etter 
hvert disse symbolene. På midten av ı970tallet var bilder av nøkler og landbrukssymboler sentrale i den politiske ikonografien og figurerte på store deler av PLOs plakater og postkort. ${ }^{\circ \circ}$ Disse symbolene og objektene fikk en verdi i det at de peker mot noe som var, og noe man skal tilbake til. Det politisk venstreradikale partiet Popular Front for the Liberation of Palestine (PFLP) var kanskje tydeligst i sin symbolbruk, da deres logo var en buet pil som pekte inn mot Palestina og som dermed symboliserte flyktningenes returrett til hjemlandet. ${ }^{3 \mathrm{I}}$ Det tapte (Palestina) ble essensen i en nåtidig tilværelse som blir ansett som et midlertidig oppholdssted (flyktningleirene) før man skal vende hjem. Nøklene og eiendomspapirene er biter av nasjonen man kan bære med seg. Hjemlengselen ble selve bærebjelken i en identitet som også fungerte som en trøst i de ekstremt fattige og isolerte flyktningleirene.

Identiteten som ble knyttet til landet var ekstra potent fordi store deler av den palestinske befolkningen hadde vært bønder. Frarøvelsen av jorda, og utkastelsen, medførte dermed en revolusjonær endring i den palestinske identiteten, derav tittelen på Rosemary Sayighs forskningsarbeid på palestinske flyktninger i Libanon: «From Peasants to Revolutionaries».32 Denne radikale endringen i det palestinske samfunnet var selvsagt del av en lengre prosess. Som nevnt fikk bøndene en fremtredende rolle i I936-opprøret. Så, ved at det palestinske lederskapet ble drevet i eksil, var det hovedsaklig vanlige palestinere, av de lavere samfunnsklasser, som stod imot sionistene. Siden konflikten hovedsaklig dreide seg om å kontrollere land fikk også den palestinske bonden en fremtredende rolle både som offer og som motstands- mann - en kombinert identitsmarkør som ble sentral.33 Det har blitt påpekt at denne koblingen er overdrevet fordi mye av Fatah/PLO-lederskapet var urbane i sitt opphav, men symbolsk, i den nasjonale mytologien, var den palestinske motstandsmannen modellert etter bonden som kjempet for landet sitt, og det gjenkjennelige palestinske skjerfet, kefiyaen, var hentet fra opprøret i i936.34 Den nye palestinske nasjonalismen som vokste opp som et resultat av I948-krigen ble del av en nedenfra-og-opp prosess, i motsetning til tidligere $i$ mandatperioden, hvor prosessen primært hadde vært ovenfra-og-ned. Det som i mandatperioden hadde sin opprinnelse i mer velstående intellektuelle, ble utover I950 og 6o-tallet utviklet og båret fram av flyktninger. ${ }^{35}$

[T]he trauma of 1948 reinforced preexisting elements of identity, sustaining and strengthening a Palestinian self-definition that was already present. The shared events of 1948 thus brought the Palestinians closer together in terms of their collective consciousness, even as they were physically dispersed all over the Middle East and beyond. ${ }^{36}$

\section{PLO og den palestinske ideologien}

Framveksten av den partikulære palestinske nasjonalismen som politisk ideologi for de palestinske partiene var en prosess som tok tid. Etter I948 var det først og fremst forskjellige typer pan-arabisk nasjonalisme som dominerte det politiske bildet blant palestinerne. ${ }^{37}$ Det første betydningsfulle palestinske partiet etter I948, Arab Nationalists' Movement (ANM), som ble grunnlagt i I95I-2, var hovedsaklig pan-arabisk i sin politiske orientering. Frigjøringen av Palestina var en integrert del av et større 
arabisk prosjekt. Det var først Fatah, grunnlagt i I958-I959, som hadde palestinsk nasjonalisme som sin primære politiske drivkraft. ${ }^{38}$ Spenningen mellom pan-arabisme og palestinsk nasjonalisme var hele tiden til stede, nettopp fordi også pan-arabisme lovte frigjøring for palestinerne. ${ }^{39}$ Den palestinske historikeren Yezid Sayigh forklarer denne tendensen slik: «The experience of al-nakba made for a distinct Palestinianness, but not necessarily for Palestinianism. Palestinians sought national salvation by joining Arab opposition parties, or hoped that new Arab leaders would come to power and launch their armies to destroy Israel and liberate Palestine." ${ }^{40}$ Likevel var det til slutt palestinsk nasjonalisme som ble den dominerende ideologien. Det var Fatah som ble det ledende partiet i PLO.

Da PLO ble grunnlagt i I964 var det først og fremst som et redskap i pan-arabisk politikk. Nasser søkte å kontrollere de palestinske motstandsbevegelsene og å utnytte den populæriteten man regnet med å få ved å støtte palestinsk frigjøring. Charteret til PLO fra I968 reflekterte dette. Palestina skulle ikke bli en egen stat, men skulle frigjøres og gjøres del av den arabiske nasjonen. Like fullt ble det fremhevet at det å være palestiner var en særegen identitet som skilte seg ut. I det opprinnelige PLO var den gamle palestinske eliten overrepresentert. Politisk snudde situasjonen etter krigen i I967 hvor det ble tydelig at araberstatene ikke maktet å beskytte palestinerne. Man måtte ta saken i egne hender. Fatah gjennomførte sine første angrep på Israel, og organisasjonen gjorde seg dermed til lederen for PLO, en posisjon de kom til å befeste utover I970- og 80-tallet. ${ }^{4 \mathrm{I}} \mathrm{I}$ araberverdenen ble denne prosessen endelig kronet med seier da Den arabiske liga på konferansen i Rabat i I974 annerkjente PLO som den «eneste legitime representant for det palestinske folk». ${ }^{2}$

Fra sin tilblivelse iverksatte PLO en oppbygging av para-statlige institusjoner som skulle fungere som en midlertig «stat» fram til frigjøringen, eller tilbakevendingen, ble gjennomført. En slik institusjonsbygging var både et uttrykk for at det fantes en nasjonalisme, og den forsterket denne. Gjennom å opprette et flagg, en nasjonalsang og en konstitusjon fikk nasjonens samlende symboler. PLO utviklet også etter hvert en nasjonal kalender hvor hendelser av betydning i palestinsk historie ble markert: Balfourdagen, delingsplandagen, nakbadagen, martyrdagen, landdagen og jubileet for Fatahs første militære aksjon, for å nevne noen. Slik ble markeringen av en felles historie et institusjonalisert nasjonal-

\section{rm \\ I den nasjonale mytologien var den palestinske motstandsmannen modellert etter bonden som kjempet for landet sitt.}

istisk rituale. ${ }^{43}$ Videre, ved å opprette og drive skoler, forskningsinstitusjoner, sykehus, et parlament, en eksil-regjering, en hær (evt. hærer/geriljagrupper) og departementer, befestet man en identitet, institusjonaliserte den og sådde frøene for at en stat kunne oppstå når tiden var inne. ${ }^{44}$ Eksempelvis kan nevnes at innen tidlig I980-tall hadde Palestinian Red Cresent Society ro sykehus og 30 klinikker, og General Union of Palestine Workers og General Union of Palestine Women hadde flere titalls tusen medlemmer. PLO ble diplom- 
atisk anerkjent av over 50 stater og fikk observatørstatus i FN. PLO hadde blitt en para-stat med stor internasjonal legitimitet og et budsjett som tilsvarte en stat. ${ }^{45}$

PLO hadde med andre ord ideologisk lyktes i sitt prosjekt med å sementere denne identiteten. De israelske akademikerne Baruch Kimmerling og Joel S. Migdal kommenterer at «[the PLO] had nurtured a national mythology of heroism and sacrifice, the portrait of the downtrodden refugee giving way to that of the feday which, in turn became the catalyst for the reconstruction of the national movement.» ${ }^{46}$ Det er viktig å påpeke her at

\section{rom \\ Ironisk nok er den palestinske nasjonalismen på mange måter et speilbilde på sionismens utvikling.}

selv om «myteskapningen» var viktig i seg selv, så var denne "heroiske ofringen" reell. Resultatet av geriljaangrepene var at både Israel og araberstatene slo tilbake med storstilte gjengjeldelsesaksjoner som straffet palestinerne kollektivt. Dette forsterket den intra-palestinske solidariteten ytterligere. ${ }^{47}$

Som det palestinske folk i sin helhet ble mange av de para-statlige institusjonene til PLO bevegelige enheter som manøvrerte i eksil. De ble utvist fra Jordan i I970 og i I982 ble de kastet ut av Libanon. De endte i Tunis før de som et resultat av Oslo-avtalene i første halvdel av I990-tallet fikk vende hjem til Palestina hvor de opprettet den palestinske administrasjonen (PA) i Gaza og deler av okkuperte Vestbredden.

Gjennom en kombinasjon av å skape en geriljahær med målsetning om å gjenvinne hjemlandet, og ved å bygge para-statlige institusjoner i flyktningleirene skapte man en eksil-nasjonalisme som, i teorien, kunne flyttes inn i det geografiske Palestina når kampen var vunnet. Det var fortiden (tiden i Palestina/det tapte paradis) og fremtiden (tilbakevendingen) som ble sentral. Nåtiden var bare en mellomfase..$^{8}$

\section{Hverken evig eller ny}

For å gå tilbake til punktene til Jan Penrose, så kan man se at det palestinske eksilsamfunnet kom til å tilfredsstille alle kravene han stiller til en nasjonalisme. Palestinerne hadde blitt en distinkt befolkningsgruppe som følte en territoriell tilknytning til et land de hadde bodd i, og de hadde hatt, og har, en felleserfaring (bonding) basert i hovedsak på en kombinasjon av erfaringene fra I936-opprøret, I948-utkastelsen og tilværelsen i eksil. PLO hadde i løpet av I960- 70- og 80-tallet befestet denne nasjonale identiteten og gitt den en parastatlig institusjonell karakter.

Den palestinske nasjonen er hverken en evig naturlig størrelse, men ei heller er det en ren reaksjon på Israels opprettelse. De kulturelle og geografiske identitsmarkørene som palestinsk nasjonalisme bygde på lå allerede i samfunnet, men palestinernes forhold til disse var ikke automatisk av nasjonalistisk art. Som alle former for nasjonalisme i verden har utviklingen av palestinsk nasjonalisme vært dynamisk. Opprinnelig oppstod palestinsk nasjonalisme som et intellektuelt eliteforetagende $\mathrm{i}$ Palestina på I9ıo-, 20- og 30-tallet. Den ble gradvis utviklet som en folkelig ideologi opp mot opprøret i i 936, og opprøret på sin side forsterket den folkelige appellen ved å spre den til alle samfunnslag. Likevel var det flukten i i948 og eksilet $\mathrm{i}$ årene etterpå 


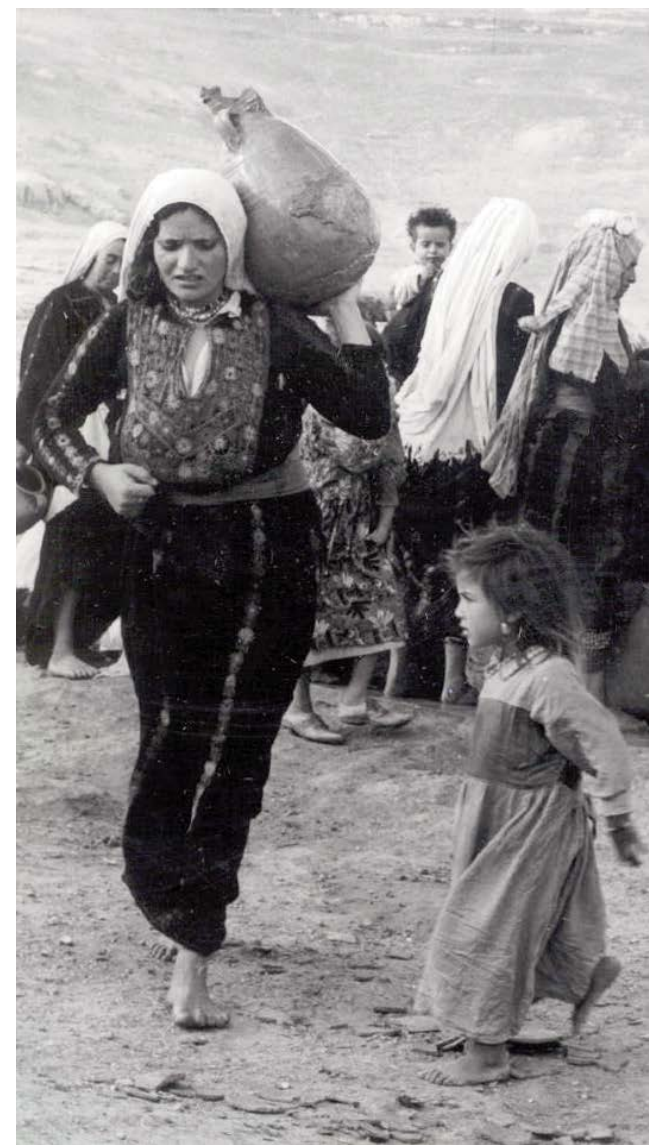

Palestinske flyktninger i I948.

som gjorde at palestinsk nasjonalisme ble befestet som en altomfattende ideologi. Den definerte den palestinske identiteten. Den palestinske forfatteren Fawzi Turki har kommentert dette så tydelig at det fortjener å bli sitert i sin helhet:

The social structure of the Palestinian family, whose atmosphere engendered a deep and constant hope for the return to Palestine, and the official discrimination against the refugee himself, created pressures that served to perpetuate the notion in the mind of the young Palestinian that he was the member of a minority, thus enhancing his Palestinian consciousness. In his home a Palestinian child, whether born in Beirut, Amman or Damascus, would be instructed to indentify himself as a Palestinian from Haifa or Lydda or any other town that had been his parents' birthplace, and his own experience would constantly remind him of this." ${ }^{2}$

Ironisk nok er den palestinske nasjonalismen på mange måter et speilbilde på sionismens utvikling. På slutten av ı8ootallet og starten av i9o0-tallet var sionismen en marginal politisk ideologi blant jøder. Det var assimilasjon som var idealet i store deler av det jødiske samfunn i Europa. Sionismen ble styrket som svar på pogrommene i Øst-Europa, og ble den dominerende ideologien som et resultat av Holocaust - jødenes store katastrofe. Som hos palestinerne er ikke jødisk nasjonalisme et evig fenomen, men det har vært et resultat av en historisk dynamikk..$^{\circ}$ Det har til og med blitt hevdet at PLO faktisk baserte mye av sin struktur på The Jewish Agency og den funksjon dette parastatlige apparatet hadde hatt for sionismen i perioden før Israel ble dannet.. ${ }^{5 \mathrm{I}}$ Begge to, PLO og The Jewish Agency, fungerte som parastatlige institusjoner som bygde nasjonen gjennom slike institusjoner og ved å befeste den nasjonale identiteten i perioden før nasjonen, som statsenhet, fikk en reell betydning. Likheten mellom disse to bevegelsene er meget ironisk sett i lys av deres historiske motstand mot hverandre. Forholdet mellom disse to passer inn i den klassiske modellen for hvordan nasjonal identitet skjer i et møte med den signifikante andre. Like ironisk er det at begge nasjonalbevegelsene har den nøyaktig samme raison d'etre: Returetten. Både sionismen og den palestinske nasjonalismen, $\mathrm{i}$ perioden etter nakbaen, har som målset- 
ning å etablere en stat hvor alle medlemmer av den gjeldende etniske gruppen skal få vende hjem. For begge er dette «hjemmet» Palestina. ${ }^{52}$ I den kampen om dominerende nasjonalismer er det sionismen som har vunnet. Ikke på grunn av et mer rettmessig krav, tvert imot, men på grunn av makt. Den jødiske returretten er et statlig prinsipp, en del av Israels lover, mens den palestinske returretten er et folkerettslig prinsipp..$^{33}$

\section{$\cdot f \cdot$}

I Schulz, Helena Lindholm: «The reconstruction of Palestinian nationalism: Between revolution and statehood». Manchester: Manchester University Press I999, s. 2.

2 Anderson, Benedict: «Imagined Communities: Reflections on the Origin and Spread of Nationalism». London/ New York: Verso, 2006.

3 Butenschøn, Nils A.: «Drømmen om Israel: Historiske og ideologiske forutsetninger for staten Israel». Oslo: Universitetsforlaget, 2006 .

4 Kimmerling, Baruch og Migdal, Joel S.: «Palestinians: The Making of a People». New York: The Free Press, 1993, s. I87.

5 Sitert i Sayigh, Yezid: «Armed Struggle and the Search for State: The Palestinian National Movement, I949-I993». Oxford: Oxford University Press, I999, s. xii.

6 Schulz, Helena Lindholm: «The reconstruction of Palestinian nationalism: Between revolution and statehood». Manchester: Manchester University Press, I999, S. I2-I3.

7 Mansfield, Peter: «The Ottoman Empire and its Successors». London/Basingstoke: Macmillan Press, I976, ss. 3I-33

8 Hobsbawm, Eric: «Nations and Nationalism since i780: Programme, Myth, Reality». Cambridge: Cambridge University Press, 2007, I37.

9 Hovdenak, Are: «Negotiating Palestine Refugees: A Question of Legitimacy». Oslo: Unpublished MA-thesis, University of Oslo, 2005, ss. 30-3I.

Io Sayigh, Yezid: «Armed Struggle and the Search for State: The Palestinian National Movement, I949-I993». Oxford: Oxford University Press, I999, 9.

II Khalidi, Rashid: «Palestinian Identity: The Construction of Modern National Consciousness». New York: Columbia University Press, I997, s. 29, 58, I53; Lindholm, Helena: «Official and Popular Palestinian Nationalism: Creations and Transformations of Nationalist Ideologies and National Identities I9I7-I993». Göteborg: Licentiate Thesis Göte borg University, I994, ss. 7I-78.
I2 Krämer, Gudrun: «A History of Palestine: From the Ottoman Conquest to the Founding of the State of Israel». Princeton: Princeton University Press, 2008, s. 267.

I3 Sorek, Tamir: "The orange and the 'Cross in the Crescent': imagining Palestine in I929" i Nations and Nationalism, IO(3), 2004, ss. 269-29I.

I4 Lindholm, Helena: «Official and Popular Palestinian Nationalism: Creations and Transformations of Nationalist Ideologies and National Identities I9I7-I993». Göte borg: Licentiate Thesis Göteborg University, I994, ss. 7982.

I5 Hovdenak, Are: «Negotiating Palestine Refugees: A Question of Legitimacy». Oslo: Unpublished MA-thesis, University of Oslo, 2005, s. 3I.

I6 Kimmerling, Baruch og Migdal, Joel S.: «Palestinians: The Making of a People». New York: The Free Press, I993, ss. 96-123.

I7 Hovdenak, Are: «Negotiating Palestine Refugees: A Question of Legitimacy». Oslo: Unpublished MA-thesis, University of Oslo, 2005, S. 3I.

I8 Schulz, Helena Lindholm: «The reconstruction of Palestinian nationalism: Between revolution and statehood». Manchester: Manchester University Press, I999, s. 29.

I9 Kimmerling, Baruch og Migdal, Joel S.: «Palestinians: The Making of a People». New York: The Free Press, I993, s. I23.

20 Avi Shlaim: «The Iron Wall: Israel and the Arab World». New York: Norton, 200I, ss. 25-53; Jensehaugen, Jørgen: “Når blir massevold politisk - I948 og den palestinske katastrofen" i Etter Lemkin 2/2009.

2I Kimmerling, Baruch og Migdal, Joel S.: «Palestinians: The Making of a People». New York: The Free Press, 1993, s. I87.

22 Hobsbawm, Eric: «Nations and Nationalism since I780: Programme, Myth, Reality». Cambridge: Cambridge University Press, 2007, S. I38.

23 Hovdenak, Are: «Negotiating Palestine Refugees: A Question of Legitimacy». Oslo: Unpublished MA-thesis, University of Oslo, 2005, ss. 33-34

24 Kimmerling, Baruch og Migdal, Joel S.: «Palestinians: The Making of a People». New York: The Free Press, I993, s. 203.

25 Gilen, Signe et al.: «Finding Ways: Palestinian Strategies in Changing Environments». Oslo: FAFO, I994, ss. 52-53, 55-59; Hovdenak, Are: «Negotiating Palestine Refugees: A Question of Legitimacy». Oslo: Unpublished MA-thesis, University of Oslo, 2005, ss. 34-35.

26 Schulz, Helena Lindholm: «The reconstruction of Palestinian nationalism: Between revolution and statehood». Manchester: Manchester University Press, I999, s. 7; Hovdenak, Are: «Negotiating Palestine Refugees: A Question of Legitimacy». Oslo: Unpublished MA-thesis, University of Oslo, 2005, ss. 40-4I.

27 Darwish, Mahmoud: «Unfortunatly, It Was Paradise». Berkeley/Los Angeles/ London: University of California Press, 2003; Darwish, Mahmoud: «The Adam of Two 
Edens». New York: Syracuse University Press, 2000, s. I54, I65.

28 Jensehaugen, Jørgen: «Al-Nakba: Eksistensiell historie skrivning» i Babylon 2/2008, Ss. I00-I07.

29 Fisk, Robert: «Pity the Nation: Lebanon at War». Oxford: Oxford University Press, 200I, Ss. I8-2I.

30 Khalili, Laleh: "Grass-Roots Commemorations: Remembering the Land in the Camps of Lebanon" i Journal of Palestine Studies, Vol. 34, No. I, 2004, s. 8.

3I Hovdenak, Are: «Negotiating Palestine Refugees: A Question of Legitimacy». Oslo: Unpublished MA-thesis, University of Oslo, 2005 , s. 36 .

32 Sayigh, Rosemary: «Palestinians: From Peasants to Revolutionaries». London/New Jersey: Zed Books, I99I.

33 Schulz, Helena Lindholm: «The reconstruction of Palestinian nationalism: Between revolution and statehood». Manchester: Manchester University Press, I999, ss. 3738.

34 Kimmerling, Baruch og Migdal, Joel S.: «Palestinians: The Making of a People». New York: The Free Press, I993, s. $2 \mathrm{I} 2$.

35 Kimmerling, Baruch og Migdal, Joel S.: «Palestinians: The Making of a People». New York: The Free Press, I993, s. I87.

36 Khalidi, Rashid: «Palestinian Identity: The Construction of Modern National Consciousness». New York: Columbia University Press, I997, s. 22.

37 Schulz, Helena Lindholm: «The reconstruction of Palestinian nationalism: Between revolution and statehood». Manchester: Manchester University Press, I999, ss. 303I.

38 Sayigh, Yezid: “The Palestinians" i Sayigh, Yezid og Shlaim, Avi (red.): «The Cold War and the Middle East». Oxford: Clarendon Press, I997, ss. I27-I28.

39 Kimmerling, Baruch og Migdal, Joel S.: «Palestinians: The Making of a People». New York: The Free Press, I993, ss. I96-I97.

40 Sayigh, Yezid: «Armed Struggle and the Search for State: The Palestinian National Movement, I949-I993». Oxford: Oxford University Press, I999, s. 666.

4I Schulz, Helena Lindholm: «The reconstruction of Palestinian nationalism: Between revolution and statehood». Manchester: Manchester University Press, I999, ss. 33-37.

42 Decisions of the Arab Summit Conference, Rabat, 30 October I974: http://unispal.un.org/UNISPAL.nsf/ eed216406b50bf6485256ceroo72f637/63d9a930e2b 428df852572c00o6do6b8?OpenDocument (OI.IO.09). Oversatt fra engelsk av forfatter.

43 Khalili, Laleh: "Grass-Roots Commemorations: Remembering the Land in the Camps of Lebanon" i Journal of Palestine Studies, Vol. 34, No. I, 2004, s. 8.

44 Schulz, Helena Lindholm: «The reconstruction of Palestinian nationalism: Between revolution and statehood».
Manchester: Manchester University Press, I999, ss. 394I.

45 Kimmerling, Baruch og Migdal, Joel S.: «Palestinians: The Making of a People». New York: The Free Press, I993, ss. 232-233.

46 Kimmerling, Baruch og Migdal, Joel S.: «Palestinians: The Making of a People». New York: The Free Press, 1993, s. 239.

47 Hovdenak, Are: «Negotiating Palestine Refugees: A Question of Legitimacy». Oslo: Unpublished MA-thesis, University of Oslo, 2005, ss. 38-39.

48 Schulz, Helena Lindholm: «The reconstruction of Palestinian nationalism: Between revolution and statehood». Manchester: Manchester University Press I999, s. 4I; Lindholm, Helena: «Official and Popular Palestinian Nationalism: Creations and Transformations of Nationalist Ideologies and National Identities I9I7-I993». Göteborg: Licentiate Thesis Göteborg University, I994, S. I05.

49 Sitert i Kimmerling, Baruch og Migdal, Joel S.: «Palestinians: The Making of a People». New York: The Free Press, I993, s. 202.

50 Butenschøn, Nils A.: «Drømmen om Israel: Historiske og ideologiske forutsetninger for staten Israel». Oslo: Universitetsforlaget, 2006 .

5I Kimmerling, Baruch og Migdal, Joel S.: «Palestinians: The Making of a People». New York: The Free Press, 1993, s. $2 \mathrm{I} 6$.

52 For palestinerne se: Hovdenak, Are: "The Palestinian Strategy in the Oslo Process" i Journal of Refugee Studies, Vol. 22, Nr. I, 2008, ss. 30, 33-36. For Israel se: Koestler, Arthur: «Promise and Fulfilment». London: MacMillan \& Co, 1949, s. 332.

53 Kattan, Victor: «From Coexistence to Conquest: International Law and the Origins of the Arab-Israeli Conflict, I89I-I949». London/New York: Pluto Press, 2009, ss. 209-23I. 